\title{
Application of biochemical and polymerase chain reaction assays for identification of Campylobacter isolates from non-human primates
}

\author{
Mônica de Castro Britto Vilardo, Jacqueline Darc da Silva Thomé, \\ Wagner Thadeu Cardoso Esteves, Ana Luzia Lauria Filgueiras $/{ }^{+}$, Selma Soares de 0 liveira*
}

Laboratório de Zoonoses Bacterianas, Departamento de Bacteriologia, Instituto Oswaldo Cruz-Fiocruz, Av. Brasil 4365, 21045-900 Rio de Janeiro, RJ, Brasil *Laboratório de Genética de Bactérias Associadas a Alimentos, Departamento de Microbiologia Geral, Instituto de Microbiologia Prof. Paulo de Goés, UFRJ, Rio de Janeiro, RJ, Brasil

A multiplex polymerase chain reaction (PCR) assay was performed on 167 thermophilic campylobacters isolated from non-human primates. Samples were first identified by phenotypic methods resulting in 64 Campylobacter jejuni and 103 C. coli strains. Four strains identified biochemically as C. coli, were then determined to be C. jejuni by PCR. Comparison of methodologies showed that the main discrepancies were attributed to the hippurate hydrolysis test and sensitivity to cephalothin and nalidixic acid. Analysis of data showed that the application of phenotypic methods should be supplemented by a molecular method to offer a more reliable Campylobacter identification.

Key words: Campylobacter - identification - non-human primates

The Campylobacter genus comprises a group of strictly related Gram-negative bacteria that are usually found colonizing the gastrointestinal tract of a variety of warm-blooded animals. For more than 40 decades Campylobacter spp. were related to veterinary diseases. However, since the development of an appropriate selective medium in the 1970s, Campylobacter isolations have increased and the bacteria have become the most commonly recognised cause of human gastroenteritis in developed countries (Butzler 2004). In spite of the relevance of Campylobacter infections, epidemiological tracing of enteritis is poorly understood in developing countries, probably due to a combination of characteristics such as the lack of seasonal variation, milder illness, the high rates of assymptomatic carriage and the high rates of infections with multiple pathogens (Taylor 1992). Furthermore, many clinical laboratories commonly do not identify Campylobacter strains to species level, since they are fastidious organisms and only a reduced number of biochemical tests are available.

C. jejuni and C. coli are the thermophilic species most frequently isolated from stool samples. Although clinical manifestations of Campylobacter enteritis are very similar with acute diarrhoea, fever and mainly abdominal cramps, $C$. jejuni is responsible for the majority (80-90\%) of infections and some serotypes are involved in GüillainBarré syndrome (Allos e Taylor 1998).

Endemic campylobacteriosis is frequent with laboratory animals that are housed in groups where fecal con-

+Corresponding author: analu@ioc.fiocruz.br

Received 4 November 2005

Accepted 26 May 2006 tamination occurs. Several non-human primates mantained in captive colonies become routinely infected with multiple Penner serotypes of $C$. jejuni and C. coli and animal enteritis share similar clinical signs to human disease (Bryant 1983, Russel 1992). The aim of this study is to improve epidemiological studies by the identification of thermophilic Campylobacter strains isolated from nonhuman primates. Because discrimination among thermophilic strains is based on only a few biochemical tests which are sometimes difficult to perform and interpret, we applied a PCR assay to get a definitive sample identification.

\section{MATERIAL AND METHODS}

Strains - For this study 167 thermophilic Campylobacter isolates were selected. Strains were isolated from the faeces of Macaca mulatta, M. fascicularis, and Saimiri sp. collected during a medical management which occurred in 1999. These animals are held in a closed colony at the Primatology Department of the Center for Laboratory Animal Breeding at the Oswaldo Cruz FoundationFiocruz.

Treatment of specimens - Bacteria were grown on Columbia agar supplemented with defibrinated sheep blood $(5 \%)$ or activated coal $(0.4 \mathrm{~g} \%)$, and also included an FBP solution. Plates were incubated $\left(42^{\circ} \mathrm{C}\right.$ for $\left.48 \mathrm{~h}\right)$ under a microaerophilic atmosphere. Campylobacter strains were identified by a classic biochemical methodology according to Filgueiras and Hofer (1989) and stored in tubes containing Peptonated water, $\mathrm{pH} 7.0-7.2$, with $20 \%$ glycerol at $-70^{\circ} \mathrm{C}$. C. jejuni ATCC 33560 and $C$. coli ATCC 33559 strains were included in all tests as positive controls.

Identification of Campylobacter spp. by multiplex $P C R$ - Genotypic identification of Campylobacter strains was performed by PCR multiplex as described by Harmon et al. (1997). The primers (Invitrogen Brasil Ltda.) used 
were pg3 (5'- GAACTTGAACCGATTTG - 3') and pg50 (5'- ATGGGATTTCGTATTAAC - 3') for gene flaA present in $C$. jejuni and $C$. coli and primers C1 (5'- CAAATAAA GTTAGAGGTAGAATGT-3') and C4 (5'-GGATAAGCAC TAGCTAGCTGAT - 3') for a non-determined gene of C. jejuni.

DNA samples - Some colonies from Columbia agar plate were resuspended in $100 \mu \mathrm{l}$ of sterile TE buffer $(10 \mathrm{Mm}$ Tris, $1 \mathrm{Mm}$ EDTA, pH 8.0) in order to obtain $2 \times 10^{9}$ cells (Englen and Kelley 2000). DNA extractions for PCR assay were done by two different protocols: the boiling method of Van Eys et al. (1989), and the method of Pitcher et al. (1989), which uses guanidine thiocyanate as a chaotropic agent. The DNA concentration was estimated in the GeneQuant pro/RNA/DNA calculator - Amersham Pharmacia Biotech.

DNA amplification - The amplification reaction was performed in a volume of $50 \mu 1$ containg: $20 \mathrm{ng}$ of sample DNA, $10 \mathrm{mM}$ of Tris-HCL; $50 \mathrm{mM}$ of $\mathrm{KCl} ; 200 \mathrm{mM}$ of (each) dATP, dCTP, dGTP, dTTP; $5.5 \mathrm{mM}$ of $\mathrm{MgCl}_{2} ; 20$ pmoles each of $\mathrm{C} 1$ and $\mathrm{C} 4 ; 40$ pmoles each of $\mathrm{pg} 3$ and pg50 and $1.25 \mathrm{U}$ of Taq DNA polymerase. All components of the mix were synthesized by Invitrogen and each amplification reactions contained positive controls of $C$. jejuni ATCC 33560 and C. coli ATCC 33559.

Reaction mixtures were amplified in a thermocycler device PTC 150 - MJ Research, Incorporation. The samples were subjected to an initial denaturation step at $94^{\circ} \mathrm{C}$ for 4 min followed by 25 amplification cycles, each one consisted of $1 \mathrm{~min}$ at $94^{\circ} \mathrm{C}, 1 \mathrm{~min}$ at $45^{\circ} \mathrm{C}$, and $1 \mathrm{~min}$ at $72^{\circ} \mathrm{C}$, ending with a primer extension step of $7 \mathrm{~min}$ at $72^{\circ} \mathrm{C}$.

Analysis of amplified fragments - PCR reaction products were separated through electrophoresis on a $1.5 \%$ agarose gel (TBE $0.5 \times$ ), including the $100 \mathrm{pb}$ ladder as molecular weight marker (Invitrogen). Agarose gels were stained in an ethidium bromide solution and visualized under UV light, in the transiluminator (Chemical Company T102 SIGMA).

\section{RESULTS}

All 167 strains of Campylobacter spp. were identified using both biochemical and multiplex PCR techniques. The use of multiplex PCR resulted in the identification of 64 strains as $C$. jejuni and 103 as $C$. coli. C. jejuni strains showed both $460 \mathrm{bp}$ to $160 \mathrm{bp}$ fragments whereas $C$. coli generated only the $460 \mathrm{bp}$ fragment (Figure). The molecular technique and the conventional phenotypic tests were in agreement for 163 of the 167 isolates. Four strains (2.84\%), firstly identified as $C$. coli, based on their inability to hydrolyze sodium hippurate, were later identified as C. jejuni by PCR. Multiplex PCR and sodium hippurate hydrolysis tests were repeated for three times and these strains were then recognized as hippurate-negative $C$. jejuni. Six strains of $C$. coli and two of $C$. jejuni that showed nalidixic acid resistance were also identified by multiplex PCR. As results were in agreement with biochemical identification these strains were then characterized as nalidixic acid resistant $C$. coli and $C$. jejuni.
Initially, DNA was extracted by the boiling water method. However, for 46 (out of 167) strains, the DNA obtained by this technique was not amplified. This group of strains was then submitted to a DNA extraction by the guanidine thiocyanate method and all of them were subsequently amplified (Table). Thirty-three (71.74\%), out of these 46 strains, were DNAse positive in biochemical tests.

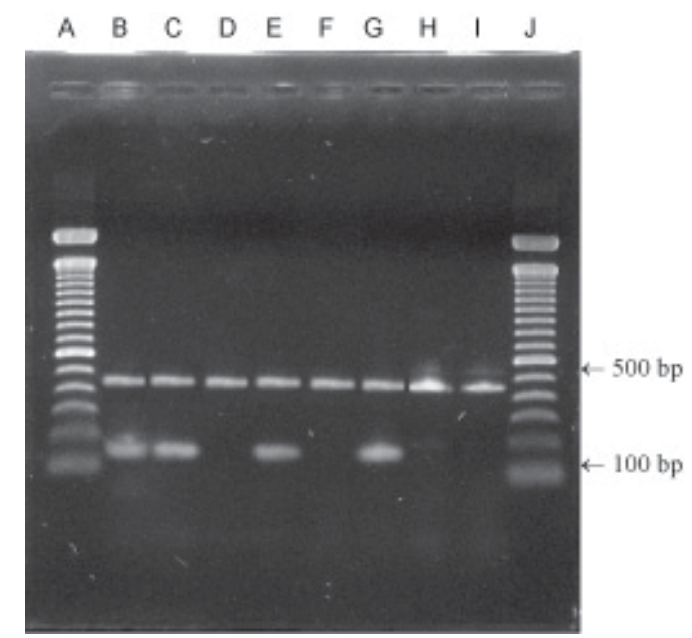

Polymerase chain reaction multiplex profile of Campylobacter jejuni (lanes B, C, E, G) and C. coli (lanes D, F, H, I) strains used in this work. Lanes A and J contain the 100 bp ladder DNA marker (Invitrogen).

\section{TABLE}

Comparative view of polymerase chain reaction amplification ability of target DNA obtained by boiling and Guanidine extraction methods

\begin{tabular}{|c|c|c|c|}
\hline Strains & $\begin{array}{c}\text { DNA } \\
\text { (boiling) } \\
\mathrm{N}(\%)\end{array}$ & $\begin{array}{c}\text { DNA } \\
\text { (Guanidine) } \\
\mathrm{N}(\%)\end{array}$ & $\begin{array}{c}\text { Total } \\
\text { N }(\%)\end{array}$ \\
\hline Campylobacter jejuni & $51(79.69)$ & $13(20.31)$ & $64(38.33)$ \\
\hline C. coli & $70(67.96)$ & $33(32.04)$ & $103(61.67)$ \\
\hline Total & $121(72.45)$ & $46(27.55)$ & $167(100)$ \\
\hline
\end{tabular}

\section{DISCUSSION}

Epidemiological studies have demonstrated a distinct pattern of Campylobacter enteritis between industrialized and developing countries, including clinical manifestations and relevancy of infections. Few published studies are realized in the developing world since the majority of public health laboratories do not have success in isolating campylobacters, which require an adequate selective media, temperature and microaerophilic conditions for incubation. These steps are not included in laboratory routines for common enteric pathogens.

In attempt to contribute to a better understanding of campylobacteriosis in Brazil, the Zoonosis Laboratory has been undertaking studies with strains isolated from several sources. A major number of isolates was obtained from non-human primates living in closed groups, which 
are frequently colonized by different strains of Campylobacter (Russel et al. 1988).

The low biochemical activity of Campylobacter spp. and the occurence of ambiguous results makes phenotypic identification difficult. Uncommon phenotypes like $C$. jejuni and $C$. coli strains which are resistant to quinolones as well as the hippurate-negative $C$. jejuni strains are frequently pointed out (Rautelin et al. 1999, Nachankin et al. 2000). Molecular techniques, including the PCR, have recently been successfully used for the identification of Campylobacter species (Steinhauserova et al. 2001). There is a large use of Campylobacter flagellum genes as sequences for PCR primers because they are highly conserved within different strains (Wegmüeller et al. 1993). The use of primers pg3 and pg50 specific for C. jejuni and C. coli are described in other publications (Oyofo et al. 1992, Aquino et al. 2001) and show a high sensitivity of detection. In the present study, as well as phenotypic identification, multiplex PCR proposed by Harmon et al. (1997) was used to distinguish C. jejuni from C. coli strains. However, 46 (27.55\%) strains did not give amplification when the boiling method was used for DNA extraction. As Mohran et al. (1998) related the existence of a differing ability of Campylobacter to display its genome by the boiling method, a second method using guanidine thiocyanate was chosen. The 46 strains showing a phenotype resistant to boiling were then amplified by the last method and it was observed that in this group, there was a high prevalence of DNAse producing strains (71.74\%).

Lai-King et al. (1997) recommended attention when processing DNAse positive Campylobacter spp. because their DNA is more difficult to detect using nucleid acidbased methods when compared with other genera. We considered that DNA extraction using guanidine thiocyanate was the best method for which it becomes possible to obtain target DNA from DNAse positive strains.

The differences in Campylobacter identification by phenotypic and PCR assays have shown that an application of a molecular analysis is essential to complement classic biochemical methodology. Our results, together with the literature, suggest that multiplex PCR can be helpful in resolving ambiguous results, for characterizing uncommon strains, and for epidemiological investigations.

\section{ACKNOWLEDGMENTS}

To Ângela Lopes Norte, chief of International Cooperation Division from Cefet-RJ, Brazil, and Dr Lawrence Price from Health Canada, National Microbiology Laboratory for reviewing the manuscript

\section{REFERENCES}

Allos BM, Taylor DN 1998. Campylobacter infections. In AS Evans, PS Brachman (eds), Bacterial Infections of Humans: Epidemiology and Control, 3rd ed., Phenum Medical Book, New York, p.169-190.

Aquino, MHC, Mangia AHR, Filgueiras ALL, Teixeira LM, Ferreira MCS, Tibana A 2002. Use of Multiplex PCR-based assay to differentiate Campylobacter jejuni e Campylobacter coli strains from human and animal sources. Vet $J$ 163: 102-104.
Bryant JL, Stills HF, Lentsch RH, Middleton CC 1983. Campylobacter jejuni isolated from patas monkeys with diarrhea. Lab An Sci 33: 303-305.

Butzler J-P 2004. Campylobacter, from obscurity to celebrity. Clin Microbiol Infect 10: 868-876.

Engley MD, Kelley LC 2000. A rapid DNA isolation procedure for the identification of Campylobacter jejuni by the polymerase chain reaction. Lett Appl Microbiol 31: 421-426.

Filgueiras ALL, Hofer E 1989. Ocorrência de Campylobacter termofílico em diferentes pontos de uma estação de tratamento de esgotos na cidade do Rio de Janeiro, RJ. Rev Microbiol 20: 303-308.

Harmon KM, Ramsom GM, Wesley IV 1997. Differentiation of Campylobacter jejuni and Campylobacter coli by polymerase chain reaction. Mol Cell Probes 11: 195-200.

Lai-King NG, Kingombe CIB, Yan W, Taylor DE, Hiratsuka K, Mailk N, Garcia MM 1997. Specific detection and confirmation of Campylobacter jejuni by DNA hybridization and PCR. Appl Environ Microbiol 63: 4558-4563.

Morhan ZS, Arthur RR, Oyofo BA, Peruski LF, Wasfy MO, Ismail TF, Murphy JR 1998. Differentiation of Campylobacter isolates on the basis of sensitivity to boiling in water as measured by PCR-detectable DNA. Appl Environ Microbiol 64: 363-365.

Nachankin I, Engberg J, Aarestrup FM 2000. Diagnosis and antimicrobial susceptibility of Campylobacter species. In I Nachankin, MJ Blaser (eds), Campylobacter, 2nd ed., ASM Press, Washington, D.C, p. 3-26.

Oyofo BA, Thornton SA, Burr DH, Trust TJ, Pavlovskis OR, Guerry P 1992. Specific detection of Campylobacter jejuni and Campylobacter coli by using polymerase chain reaction. J Clin Microbiol 30: 2613-2619.

Pitcher DG, Saunders NA, Owen RJ 1989. Rapid extraction of bacterial genomic DNA with guanidine thiocyanate. Lett Appl Microbiol 8: 151-156.

Rautelin H, Jusufovic J, Hänninem MJ 1999. Identification of hippurate negative thermophilic campylobacters. Diag Microbiol Infect Dis 35: 9-12.

Russel RG 1992. Campylobacter jejuni colitis and immunity in primates: epidemiology of natural infection. In I Nachamkin, MJ Blaser, LS Tompkins(eds), Campylobacter jejuni: Current Status and Future Trends, American Society for Microbiology, Washington, p. 148-157.

Russel RG, Krugner L, Tsai C-C, Ekstrom R 1988. Prevalence of Campylobacter in infant, juvenile and adult laboratory primates. Lab Anim Sci 38: 711-714.

Steinhauserova I, Ceskova J, Fojtikova K, Obrovska I 2001. Identification of thermophilic Campylobacter spp. by phenotypic and molecular methods. J Appl Microbiol 90: 470475.

Taylor D N 1992. Campylobacter infections in developing countries. In I Nachamkin, MJ Blaser, LS Tompkins (eds), Campylobacter jejuni: Current Status and Future Trends, American Society for Microbiology, Washington, p. 20-30.

Van Eys GJJM, Gravekamp C, Gerritsen MJ, Quint W, Cornelissen MTE, Ter Schegget J, Terpstra WJ 1989. Detection of leptospires in urine by polymerase chain reaction. $J$ Clin Microbiol 27: 2258-2262. 